\title{
The Petroleum War of 1910: Standard Oil, Austria, and the Limits of the Multinational Corporation
}

\section{Citation}

Frank, Alison. 2009. The Petroleum War of 1910: Standard Oil, Austria, and the limits of the multinational corporation. The American Historical Review 114(1): 16-41.

\section{Published Version}

http://dx.doi.org/10.1086/ahr.114.1.16

\section{Permanent link}

http://nrs.harvard.edu/urn-3:HUL.InstRepos:2710386

\section{Terms of Use}

This article was downloaded from Harvard University's DASH repository, and is made available under the terms and conditions applicable to Other Posted Material, as set forth at http:// nrs.harvard.edu/urn-3:HUL.InstRepos:dash.current.terms-of-use\#LAA

\section{Share Your Story}

The Harvard community has made this article openly available.

Please share how this access benefits you. Submit a story.

\section{Accessibility}




\title{
The Petroleum War of 1910: Standard Oil, Austria, and the Limits of the Multinational Corporation
}

\author{
ALISON FRANK
}

“The PROPRiEtor of STOCK," AdAm SMith CONTENDEd in 1776, "is properly a citizen of the world, and is not necessarily attached to any particular country." The mobility of the stockholder, like that of the merchant-who Smith likewise noted was "not necessarily the citizen of any particular country" - challenged the modern state trying to develop its own economy. The stockholder could invest abroad to avoid paying an obnoxious tax; worse yet, "a very trifling disgust will make [the merchant] remove his capital, and together with it all the industry which it supports, from one country to another." In the twenty-first century, this observation has inspired studies of international economic activity that, despite myriad disagreements, tend to agree that "globalization challenges the importance of the nation-state and alters the balance of power between states and markets in favor of the latter," and that the major beneficiaries of this phenomenon are multinational corporations. ${ }^{2}$ Even in the Golden Age of global commerce that preceded the First World War, however, merchants and stockholders could not, in every instance, simply turn tail and flee over a "trifling disgust." Instead, they had to negotiate terms and reach settlements with a profusion of imperial, national, provincial, and local governments. ${ }^{3}$ This was particularly true of the oil industry, which had reached global proportions by that time. From 1910 to 1912, two of the world's most powerful corporate entities- "the best known of all international companies," the Standard Oil Trust, and the second-larg-

The author thanks Sven Beckert, David Ciarlo, Pieter Judson, Hoi-eun Kim, Mary Lewis, Malinda Maynor Lowery, Charles Maier, Terry Martin, Devin Pendas, Emma Rothschild, Daniel Smail, Rachel St. John, Judith Surkis, Tara Zahra, Jonathan Zatlin, Jane Lyle, Robert Schneider, and the $A H R$ 's anonymous reviewers for comments on drafts of this article. She also thanks Matt Olsen, National Archives and Records Administration, College Park, Maryland; Herbert Hutterer, Österreichisches Staatsarchiv, Vienna, Austria; Roger Nougaret, Archives historiques du Crédit Lyonnais, Paris, France; and Myroslava Diadiuk, Tsentral'nyi Derzhavnyi Istorychnyi Arkhiv Ukraïny, L'viv, Ukraine.

1 Adam Smith, An Inquiry into the Nature and Causes of the Wealth of Nations (London, 1776). Stockholder: Book V, chap. II, art. 2, para. 6; Merchant: Book III, chap. IV, para. 24.

2 Jürgen Osterhammel and Niels Petersson, Globalization: A Short History, trans. Dona Geyer (Princeton, N.J., 2005), 6.

${ }^{3}$ Frederick Cooper, "What Is the Concept of Globalization Good For? An African Historian's Perspective," African Affairs 100 (2001): 194. Cooper notes: "for all the growth in international trade in recent decades, as a percentage of world GDP it has only barely regained levels found before the First World War." Kevin H. O'Rourke and Jeffrey G. Williamson argue that "world capital markets were almost certainly as well integrated in the 1890s as they were in the 1990s." O'Rourke and Williamson, "When Did Globalisation Begin?" European Review of Economic History 6 (2002): 4. See also David Armitage, "Is There a Pre-History of Globalization?" in Deborah Cohen and Maura O'Connor, eds., Comparison and History: Europe in Cross-National Perspective (New York, 2004), 165-176. 
est country by population in Europe, Austria-Hungary-engaged in a bitter, protracted dispute that Austria's leading daily newspaper dubbed a "Petroleum War."4 On the surface a conflict about Austria's regulation of Standard's activities within the empire, the Petroleum War epitomized the fundamental riddle of capitalist development in this period: even powerful multinational corporations with global pretensions were associated with-and in some instances beholden to-national governments. To the extent that the turn of the century was a globalized age, and most historians accept that it was, international capitalism did not diminish the significance of states.

The outcome of the Petroleum War would lead Standard's chief diplomat, William Herbert Libby, to conclude, "American capital invested abroad-even in accord with the strictest treaty provisos-may be subjected to the most arbitrary and inequitable treatment by a foreign government, because neither the American Executive nor the Department of State is vested with any discretionary power to adoptwhatever the crisis - suitable retaliatory action or adequate industrial reprisals."5 Libby's indignation reminds us that more than oil was at stake in this dispute. At its heart lay two incompatible approaches to the question of sovereignty-in particular, the nature of foreign stockholders' rights in a domestically incorporated joint stock company. It was not, strictly speaking, Standard that had run into trouble in Austria, but rather a Viennese subsidiary that was legally an Austrian company, and not an American one at all. This raised the question of how to determine a company's "nationality." Was it based on the firm's legal site of incorporation? The citizenship of its board of directors, or of its major shareholders? The location of its production facilities, or of its consumer markets? The answer to these questions was more than academic: access to the largest consumer markets in Europe hung in the balance. To prod the State Department into action, Standard argued that not just oil revenue, but in fact all American stockholders' foreign investments were at risk.

Libby's dilemma exposes the fluidity between companies' national and multinational identification at the same time that it demonstrates the value of stubbornly international business history. Capitalism in this period, despite individual companies' penchants for border-crossing, was deeply national-even if the historical community increasingly recognizes its effects as transnational. Heads of corporations and heads of state alike operated in a paradoxical political and economic climate characterized by what Eric Hobsbawm called "the strange schizophrenia of the capitalist world economy" - at once internationalist and organized around national economies. ${ }^{6}$ Multinational corporations-in particular, oil companies-could get caught between the international markets in which they operated and the national governments whose support they sometimes needed to protect their extended opera-

${ }^{4}$ Mira Wilkins, The Emergence of Multinational Enterprise: American Business Abroad from the Colonial Era to 1914 (Cambridge, Mass., 1970), 62. Austria-Hungary, with a population of 49,418,600, had more residents than all of South America (48,946,437). The Library Atlas of the World, vol. 2: Foreign Countries (Chicago, 1912), 110. "Der Petroleumkrieg," Neue Freie Presse (Vienna), September 24, 1910.

5 William Herbert Libby to Secretary of State Philander Chase Knox, December 20, 1912, National Archives and Records Administration, Record Group 59, College Park, Md., Decimal File 1910-1929 [hereafter NARA, RG 59], Box 4462, 363.113 V 13/95.

${ }^{6}$ Eric Hobsbawm, The Age of Empire, 1875-1914 (New York, 1989), 40, 41, 54. See also Charles Maier, "Consigning the Twentieth Century to History: Alternative Narratives for the Modern Era," American Historical Review 105, no. 3 (June 2000): 808. 
tions. Like other multinational firms, oil companies often functioned through subsidiaries founded as "national" joint stock companies and incorporated according to the regulations of a particular state. ${ }^{7}$ These companies were beholden to stockholders and run by merchants who, according to Smith, were stateless-but they were taxed and regulated locally. ${ }^{8}$

In countless ways, oil companies' successful operations depended on the benevolence of states. Vertically integrated oil companies had to secure access to crude oil in areas of production, transport that oil to refining facilities, and arrange for the distribution of refined products to consumer markets; sometimes each of these stages occurred on a different continent. And in each context, oil companies had to navigate through wide varieties of tax regimes, tariffs on crude and/or refined products, procedures for granting concessions, regulations controlling exploration and extraction rights, laws linking mineral rights to or dividing them from land ownership, labor laws, and widely diverse levels of infrastructure enabling or limiting distribution, including railroads. This created not only situations where state interference could become a matter of more than "trifling disgust" for corporations, but also situations in which only proactive state support could enable corporations to continue operation.

To say that states were, in the words of Hobsbawm, the "basic building-blocks" of the capitalist world economy, however, is not to say that they were monolithic or even consistent in representing "national interest." "After all, Standard Oil's request for State Department assistance on behalf of its Austrian subsidiary was synchronous with the Justice Department's prosecution of Standard Oil before the Supreme Court. The same federal government that made Standard the target of investigation and prosecution at home aggressively advocated its foreign operations-even borrowing Libby's language to make its case. The extended confrontation between Standard, the U.S. Department of State, Austria-Hungary, and Austrian refiners thus exposes both the interdependence of diplomats and captains of industry, governments and nongovernmental organizations (including for-profit corporations), and also their ability to take different positions in different contexts.

The Petroleum War was waged not only between states, but also within and across them, and to study it requires breaking down barriers between state and non-state agents. In both Austria and the United States, a dizzying array of actors, some outward-looking, some inward-looking, some governmental, some private, participated in this dispute. Within the imperial government in Vienna, there were no fewer than five ministries responsible for overseeing various aspects of the oil industry. Alternately at odds with and beholden to the imperial government were Galician crude oil producers, Galician petroleum refiners, other Austrian petroleum refiners, Aus-

7 Alice Teichova, "Multinationals in Perspective," in Alice Teichova, Maurice Lévy-Leboyer, and Helga Nussbaum, eds., Multinational Enterprise in Historical Perspective (Cambridge, 1986), 364.

8 Practical considerations such as "transport costs and other transaction costs" also hampered the mobility of multinational corporations. Dani Rodrik, "Symposium on Globalization in Perspective: An Introduction," Journal of Economic Perspectives 12, no. 4 (1998): 4. Factors tying multinational corporations to a particular area include "the control and exploitation of . . . raw material," "domination of the entire world market or part of it for a certain product," the evasion of "tariffs which would be imposed were the goods imported," and acquiring "a foothold in one country by participating in its economic life for further expansion to other countries." Teichova, "Multinationals in Perspective," 367.

${ }^{9}$ Hobsbawm, The Age of Empire, 40. 
trian consumers, and Austrian petroleum wholesalers and retailers. An equally wide range of persons and institutions were involved on the American side. Standard acted within Austria through its Austrian subsidiary, Vacuum Oil Company AG, Vienna, but let Libby direct its negotiations with the State Department in Washington, D.C., directly from his Manhattan office. Within the State Department, responsibility for managing the crisis was shared by the newly minted Division of Near Eastern Affairs, the Bureau of Trade Relations, the Counselor's Office, and the ambassador in Vienna. Libby looked to Congress for further assistance, and the State Department tried to involve the Department of the Treasury. The various participants had motivations, incentives, goals, and perspectives that varied synchronically from those of their allies and opponents, and diachronically, based both on external circumstances and on the experience they gained during this protracted dispute. Attempts to present a united front when interests and incentives were not only diverse but in fact irreconcilable were characteristic of European and American diplomatic relations in this period. They reflect asymmetric relationships and unexpected alliances that arose within the oil industry and in its interaction with states-relationships that complicate the notion of national interest.

Grouping historical actors according to their interests in petroleum creates links across national boundaries and nearly impermeable divisions within nation-states. A country's leading oil companies, engaged in merciless struggles with other countries' leading oil companies for global markets and access to production, could claim to need and deserve government support abroad. However, even if national governments were inclined to protect purportedly "national" industries from "foreign" competition, they were less able to discern a "universal" or "national" interest in those same companies' domestic activities. Too many different groups-producers, refiners, distributors, wholesale and retail merchants, consumers-could claim to represent that interest best. Underneath the façade of national interest-a phrase used generously by all the protagonists in this dispute-lay complex and unbalanced internal struggles for both economic power and moral authority. Nevertheless, to succeed in international markets, even companies as powerful as Standard Oil found that they needed to link their business interest to the putative national interest when calling on the state for support. Even states as prominent in their advocacy of the free market as the United States were willing to use diplomacy to promote their own business interests abroad.

The Petroleum War of 1910 was possible thanks to a historical circumstance that is easily forgotten: in that distant age, both the United States and Austria-Hungary were oil-producing states whose petroleum production vastly exceeded domestic demand. ${ }^{10}$ Thanks to its Galician oilfields, Austria-Hungary was, after the United States and the Russian Empire, the world's third-largest oil-producing country, ac-

${ }^{10}$ Harold Williamson and Arnold Daum, The American Petroleum Industry: The Age of Illumination, 1859-1899 (Evanston, Ill., 1959), 108-124. By the early 1880s, petroleum represented the United States' fourth most valuable export; ibid., 338. Ralph Hidy and Muriel Hidy, Pioneering in Big Business, 18821911 (New York, 1955), 124. The Hidy and Hidy volume is the first in a four-volume series, History of Standard Oil Company (New Jersey), made possible when, in 1947, Standard Oil agreed to open its own records to scholars over whose work it would have no control. According to the archivist responsible 
counting for 5 percent of global oil production in 1908. ${ }^{11}$ At that time, the United States was unchallenged as the global leader in oil production (with over 60 percent), and the Standard Oil Trust dominated the U.S. and western European markets. ${ }^{12}$ Thanks to recent discoveries of major new oilfields at Spindletop (1901), Masjidi-Suleiman (1908), and Tampico (1910), newcomers Texas, Persia, and Mexico were just beginning to join the ranks of global production leaders. The oil industry of 1910 featured not only different producers, but also different products and different problems. One hundred years ago, crude oil's most useful, profitable, and widespread refined product was not gasoline or fuel oil but kerosene, used to light the homes and public buildings of rural Europe and America long after it had been replaced by gas and electricity in their major cities. ${ }^{13}$ In an era in which the world's petroleum resources truly seemed limitless, securing control over markets with high demand was a greater competitive challenge than securing access to productive oil fields. Competition was particularly fierce in Europe.

Analysts at the French investment bank Le Crédit Lyonnais reported in 1908 that Galicia was the last European bastion of resistance to the American trust, other competitors appearing "to have found it more practical to get along with [their] powerful rival." 14 When Austrian refiners suffering from their own problems with domestic oversupply targeted Germany and France, they did not fundamentally threaten Standard's position. But the looming dissolution of the Trust back in the United States added a new dimension to Standard's concerns. Despite its reputation for omnipotence, Standard Oil worried, according to John D. Rockefeller's biographer, that "its monopoly was swiftly crumbling at home and overseas." After the federal circuit court in St. Louis ruled against the Trust in late 1909, and before the Supreme Court's anticipated confirmation of that decision was announced in May of 1911, Standard's authority at home and abroad seemed vulnerable to an unparalleled degree. ${ }^{15}$ Austria's entry into the western European market exacerbated Standard's fear that its carefully constructed control was fragile and threatened with collapse. Under competition not only from the organization of Austrian oil export-

for the Exxon/Mobil papers at the University of Texas, the papers referenced by the Hidys have since disappeared; it would therefore be impossible to reproduce their work.

11 The erstwhile Kingdom of Galicia and Lodomeria, which marked Austria-Hungary's border with the Russian Empire, is now divided between Poland and Ukraine. In 1895, the U.S. produced 51 percent of the world's petroleum, Russia 44 percent, and Austria-Hungary 1.4 percent. In 1909, the United States produced 61 percent, Russia 22 percent, and Austria-Hungary 5 percent. Robert Schwarz, ed., Petroleum-Vademecum: International Petroleum Tables, 7th ed. (Berlin, 1930), 2-5. On the Galician oil industry, see Alison Frank, Oil Empire: Visions of Prosperity in Austrian Galicia (Cambridge, Mass., 2005).

12 By 1908, Standard controlled an estimated 75 percent of the kerosene market in western Europe. Wilkins, The Emergence of Multinational Enterprise, 83; Hidy and Hidy, Pioneering in Big Business, 565; Michael Smith, The Emergence of Modern Business Enterprise in France, 1800-1930 (Cambridge, Mass., 2006), 424.

13 In 1904, illuminating oil accounted for 58 percent of the total output of major refinery products in the U.S. In 1909, 64.2 percent of illuminating oil produced in the U.S. was exported. However, whereas kerosene distribution grew by only 2.5 times between 1899 and 1919, fuel oil distribution in the U.S. domestic market grew by 2,500 percent. Williamson and Daum, The American Petroleum Industry, 168, 169.

14 “Note sur les Pétroles de Galicie," June 1908, Archives historiques du Crédit Lyonnais [hereafter AHCL], Direction des études économiques et financières [hereafter DEEF], 30167, Étude no. 303.2, 13.

15 Ron Chernow, Titan: The Life of John D. Rockefeller, Sr. (New York, 1998), 431, 554. 
ers, the Aktiengesellschaft für Österreichische-Ungarische Mineralölprodukte (OLEX), but also from the European Petroleum Union, British Petroleum, and Russian oil companies, Standard participated in "intensified trade tactics" to defend its European market share, turning 1910 into a year of struggle that the editor of the Petroleum Review believed would "commercially far outshine not a few international differences."16

The conflict between the Austrian government and Standard erupted in the Austrian province of Galicia, where petroleum production dated back to the 1850 s. Standard grew interested in Galicia in the 1890s, following the discovery of new beds in the Borysław basin that had caused a sudden and dramatic increase in Galician production and the plummeting of Standard's sales in the monarchy. ${ }^{17}$ Anticipating resistance to the "standardization" of Europe's domestic markets, the Trust expanded abroad under the name of one of its affiliates (in which it had acquired a 75 percent interest upon the foundation of the Standard Oil Trust in 1882): the Rochester, New York-based Vacuum Oil Company. ${ }^{18}$ Vacuum Oil Company AG, Vienna, was duly chartered, under Austrian laws of incorporation, in 1899.19 In 1904, driven by high tariffs on refined products designed to protect Galician crude oil producers and in response to the creation of OLEX, it built a large refinery in Czechowitz-Dzieditz/ Czechowice-Dziedzice, in Austrian Silesia. ${ }^{20}$ By 1910, Vacuum had about $\$ 3$ million (U.S.) invested in manufacturing plants and equipment in Austria-Hungary, not including liquid capital for commercial purposes. ${ }^{21}$

The mere presence of a Standard Oil subsidiary on Austrian soil did not inevitably lead to a diplomatic dispute. In 1910, however, the Austrian petroleum industry had reached a point of crisis that its participants recognized they could not resolve themselves. Vacuum's competitive tactics had intensified difficulties for Austrian refiners that dated back to the alleviation of a Galician overproduction crisis at the beginning of the twentieth century. When overproduction had threatened to drive producers out of business, the central government initiated an ambitious program to raise crude oil prices by constructing the largest oil refinery in non-Russian Europe, converting all public lines of the Austrian state railway from coal power to petroleum, and purchasing 1.5 million tons of crude oil annually-approximately 75 percent of all the crude expected to be produced in Galicia in the year the agreement was reached - at a rate nearly double its market value at the time. ${ }^{22}$ By raising the market

16 Petroleum Review (London) 35, no. 513 (October 7, 1911): 235-236.

17 Hidy and Hidy, Pioneering in Big Business, 131.

18 Ibid., 46-47, 110; Williamson and Daum, The American Petroleum Industry, 476.

19 When founded in 1899, it had 200,000 Austrian crowns in capital; by 1908, capitalization had increased to 20,000,000 crowns. "Vacuum Oil Company Aktien Gesellschaft à Buda Pest," October 1919, AHCL, DEEF, 30166, Note no. 4807, 1-2.

20 Another subsidiary, Vacuum Oil Company Reszvenytarsasag, Budapest, built a refinery in Almásfüzitő, Hungary. Wilkins, The Emergence of Multinational Enterprise, 87; Hidy and Hidy, Pioneering in Big Business, 513. Vacuum's director estimated the capacity of the two refineries together at about 13 percent of Austro-Hungarian production. Letter from George Washington Hooker to Charles Denby, General Consul of the United States, June 15, 1910, NARA, RG 59, Box 4461, 25024/5.

${ }^{21}$ Recognizing the importance of transportation and storage of petroleum, Standard also owned a 40 percent interest in the Galician Crude Oil Transport and Storage Company. Libby to Knox, June 15, 1910, NARA, RG 59, Box 4461, 25024. Hidy and Hidy, Pioneering in Big Business, 513.

${ }^{22}$ Stefan Sulimirski, “Stanisław Szczepanowski, Życiorys,” Przemyst Naftowy 4, no. 11 (June 1929): 324-326; Bankers Trust Company, The Sixth Country in Europe (New York, 1927), 10; Frank, Oil Empire, $165-169$. 
price for crude oil, however, the imperial government created serious problems for refiners, which were unable to pass on the increase to their customers. ${ }^{23}$ These substantial problems notwithstanding, when Austrian refiners learned that Standard Oil had entered their market (several years after the fact), they blamed their woes on the presumed interference of so powerful a rival. ${ }^{24}$

Austrian refiners believed that Standard was using Vacuum to drive them out of their own domestic market. ${ }^{25}$ According to Ludwig Neurath, the director of a leading Viennese bank (the Österreichische Credit-Anstalt für Handel und Gewerbe), Vacuum overbid other Austrian refineries' purchase offers for crude oil and underbid their prices for refined products. ${ }^{26}$ While the Austrian industry was troubled by its own internal flaws (most prominent among them a lack of sufficient organization on the part of either producers or refiners), Neurath argued in a 1910 exposé that the primary cause of its "chaotic condition" was the "business politics of Standard Oil Company, which uses its Austro-Hungarian subsidiary, Vacuum Oil Company, to carry on in the most intense manner its destructive politics in a battle against the domestic petroleum industry." 27 The trouble had started when, driven by stagnant domestic consumption and rapidly increasing production, Austrian refiners learned at the beginning of the twentieth century what Standard had long realized: access to export markets was the most significant question of the day. ${ }^{28}$ Without established export markets, efficient transportation, or adequate storage facilities, Galician refiners fell victim to every dramatic alteration in local or global production and the resulting shifts in prices. Economic analysts employed by the Crédit Lyonnais an-

23 The Austrian government strongly pressured refiners to offer stable and low consumer prices. Testimony of Sektionschsef Brosche (Handelsministerium), "Enquete über die Krise in der Mineralölindustrie," Österreichisches Staatsarchiv [hereafter ÖStA], Ministerium für öffentliche Arbeiten [hereafter MföA], F664, Z1079 XIV 1910, 10.

${ }^{24}$ Viceroy Michał Bobrzyński feared that three English companies that had purchased nearly three dozen wells along with connected pipelines in 1910 might have acquired them "at the expense of the American Standard Company." Tsentral'nyi Derzhavnyi Istorychnyi Arkhiv Ukraïny, f.146, op. 6, sp. 1338, no. 245.

${ }^{25}$ Both contemporary business analysts at the French bank Le Crédit Lyonnais and historians of Standard's European operations agree. "Note sur les Pétroles de Galicie," June 1908, AHCL, DEEF, 30167, Étude no. 303.2, 15-16; Alfred D. Chandler, Jr., Scale and Scope: The Dynamics of Industrial Capitalism (Cambridge, Mass., 1990), 439.

${ }^{26}$ Ludwig Neurath, "Massnahmen zur Sanierung der Lage der österr. Petroleumindustrie," March 5, 1910, ÖStA, MföA, F664, Z354. The Credit-Anstalt had been involved in attempts to organize the industry since at least 1902. "The Condition of the Galician Petroleum Industry," Petroleum Review, September 26, 1908, 181-182, and October 10, 1908, 199-200. Neurath, a "remarkable specialist in the petroleum industry," was a member of the governing board of thirty-one industrial enterprises. Bernard Michel, Banques et banquiers en Autriche au début du 20e siècle (Paris, 1976), 147, 160.

27 Neurath, "Massnahmen zur Sanierung der Lage der österr. Petroleumindustrie."

28 In 1909, Austria consumed only 14 percent of its own petroleum production. Galician production had exceeded Austro-Hungarian consumption every year since 1895. Joseph Mendel and Robert Schwarz, eds., Internationale Petroleumstatistik, vol. 2: Oesterreich-Ungarn (Vienna, 1912), 10. For an argument that Austria-Hungary's low level of consumption was best explained by its burdensome tax on petroleum consumption, see "Petroleum Consumption in Austria-Hungary," Petroleum Review, July $6,1907,19$. The policy of inflating domestic prices in order to subsidize lower prices abroad did not help. R. Zaloziecki, “A Review of the Galician Petroleum Industry in 1898," Petroleum Industrial and Technical Review, February 18, 1899, 9-12. On the overproduction crisis, see Frank, Oil Empire, 140, 149-155, 169-172. On Austria's consumption more broadly, see John Komlos, The Habsburg Monarchy as a Customs Union: Economic Development in Austria-Hungary in the Nineteenth Century (Princeton, N.J., 1983), 6. The Austrian overproduction crisis was only one part of a larger glut of oil initiated by an economic depression and drop in demand for oil in the Russian Empire that began in 1900. Daniel Yergin, The Prize: The Epic Quest for Oil, Money, and Power (New York, 1991), 117. 
ticipated that Austrian petroleum exports to Germany and France would lead to a battle with Standard, and they did not believe it was one that Austrian refiners could win. ${ }^{29}$ A large part of the problem for Austrian refiners was that freight costs on the Austrian railroads were notoriously uncompetitive. Since Standard could ship oil from the United States across the Atlantic to ports in Europe-including Hamburg-more cheaply than Austrian companies could send it via rail, Austrian refiners could match Standard's prices only by selling at a loss. ${ }^{30}$ At the height of overproduction, Austrian refiners were offering refined products in France at a price well below the amount charged by French refiners, hoping that by selling at a loss they might secure a foothold in the market. ${ }^{31}$ Consistent with a general tendency to hold John Rockefeller personally responsible for Standard's every step, Austrian producer/refiner William MacGarvey complained that Rockefeller "will not allow us in any country in Europe!" 32 Neurath confirmed that a decade's worth of negotiations with the Americans over European export markets had led to naught. ${ }^{33}$

Vacuum, not surprisingly, had a different perspective on the origins of its dispute with Austrian refiners. OLEX was a joint stock company that organized the export activities of Austrian refiners by "centralizing offers, allocating orders, and seeking to develop foreign sales." 34 It served only those Austrian refiners who agreed to abide by the production quotas apportioned to its members. Although many Galician refiners did not participate in OLEX, its clientele included the most powerful refining companies within Austria. ${ }^{35}$ Vacuum was dissatisfied with its proposed allotment, and subsequently refused to participate. Given that the Galician refiners who controlled OLEX's board of directors were openly known to be engaged in a "battle against competition from Vacuum Oil," Vacuum's complaints that its allotment was punitively small are credible. ${ }^{36}$ When sudden increases in production in 1909 led to

29 "Note sur les Pétroles de Galicie," June 2008, AHCL, DEEF, 30167, Étude no. 303.2, 11-12.

${ }^{30}$ In 1898, Galician petroleum was sold in Germany at prices between 17.05 and 19.80 francs, while U.S. refined oil was sold in Hamburg at 16 francs. "Prix de Revient du Pétrole Raffiné en Galicie," in "Gisements Pétrolifères de Schodnica (Galicie): Concessions de Messieurs Wolski et Odrzywolski," March 30, 1898, AHCL, DEEF, 25245, 3-4. The cost of shipping Standard's oil across the Atlantic dropped sharply with the introduction of oceangoing steam tankers in 1886 . Hidy and Hidy, Pioneering in Big Business, 145-146. Thanks to the spread of steamships and the drops in freight rates, the transportation of a ton of wheat from New York to Mannheim cost no more than the transport of the same from Berlin to Kassel. Sebastian Conrad, Globalisierung und Nation im Deutschen Kaiserreich (Munich, 2006), 39.

${ }^{31}$ According to the Journal du Pétrole, Austro-Hungarian refiners sold petroleum for 18-22 crowns/ $100 \mathrm{~kg}$ within the monarchy, but for only 3.5 crowns/100 kg in export markets. "Note sur les Pétroles de Galicie," June 1908, AHCL, DEEF, 30167, Étude no. 303.2, 10-11; Journal du Pétrole, March 1, 1908, 11.

32 "Enquete über die Krise in der Mineralölindustrie," 15. MacGarvey was born in Canada and emigrated to Galicia in the 1880 s. He was Austrian by neither citizenship nor nationality, but only by business interest-the relevant category here.

33 Neurath, "Massnahmen zur Sanierung der Lage der österr. Petroleumindustrie."

34 "Note sur les Pétroles de Galicie," June 1908, AHCL, DEEF, 30167, Étude no. 303.2, 14. Controlling shares in OLEX were owned by the Deutsche Erdöl-AG, which was in turn charged with managing the oil interests of one of the largest German banks, the Disconto-Gesellschaft. Rivalries with Standard Oil in the German market can therefore be assumed to have played some role in discrimination against Vacuum in the setting of export quotas. For a more thorough explanation of the relationship between the Disconto-Gesellschaft, Deutsche Erdöl-AG, and OLEX, see Chandler, Scale and Scope, $438-440$.

35 "Stés pétrolifères en Galicie," AHCL, DEEF, 22085, folder MB3.

36 The directors of Vacuum Oil Company AG (Vienna), Julius Weiss and George W. Hooker, claimed that they had been allotted only 110 cars of refined petroleum per year for domestic distribution, 
a dramatic drop in crude oil prices, Galician producers, lacking adequate storage facilities and facing the prospect of bankruptcy, toyed with the idea of reaching an agreement with Vacuum for storage of their crude oil. This would have put an end to the favorable prices that refiners enjoyed, and it would have enabled Vacuum to elude the restrictions that OLEX was trying to enforce. ${ }^{37}$

Recognizing that they could not win a battle with Standard on their own, refiners called on the imperial government to take action. Their faith that it would do so reflects a general consensus in Austria that the government was obliged to support domestic industry through the bureaucracy rather than the legislature. Imperial Austrian bureaucracy, dubbed Bürokretinismus (bureau-cretinism) by the acerbic Viennese wit Karl Kraus, has a bad reputation. One prominent historian of Austria could praise it only in its inefficiency, noting that "the propensity of bureaucracy to stumble over red tape engendered that 'absolutism mitigated by Schlamperei [sloppiness],' whose loopholes made life bearable in what might otherwise have been an oppressive state." 38 Such criticism notwithstanding, the imperial bureaucracy was also a cornerstone of Austrian society-in particular after the Great Depression of 1873-1896. In its aftermath, Austria moved toward a form of organized capitalism, defined by the Austrian economic historian Franz Baltzarek as "that form of economic order which bid free competitive capitalism adieu, and represented a concentrated, internally bureaucratized economic order organized through business associations and secured by state interventions." 39 According to legal historian David Gerber, in the post-depression environment, "government activity seemed to many to be the only way out of the economic doldrums." 40

True to this model, the government's reaction was swift. Prime Minister Richard Baron Bienerth asked each of the relevant ministries to submit suggestions for action. ${ }^{41}$ The minister of foreign affairs, Alois Count Aerenthal, was responsible for managing any diplomatic repercussions of a trade war with a company that the Americans claimed as their own. The minister of public works, August Ritt, ran a stateowned oil refinery in Drohobycz that was the largest purchaser of crude oil in the empire and the largest non-Russian refinery in Europe. The minister of railways, Ludwig Wrba, controlled access to tank cars, switching lines, fill stations, and other installations that enabled oil refiners to transport crude and refined oil products via rail. The minister of commerce, Richard Weiskirchner, was responsible for granting concessions to and regulating the operation of refineries and distribution organi-

while "other refineries of the same capacity were allowed a quantity of 2500 cars." Weiss and Hooker to Richard Kerens, U.S. Ambassador in Vienna, July 23, 1910, NARA, RG 59, Box 4461, 363.115 V 13.

37 Hidy and Hidy, Pioneering in Big Business, 513. On the other hand, backed by Standard and its "unlimited financial resources," Vacuum would have been able to provide sufficient storage facilities to make price collapse caused by overproduction a thing of the past. "The Standard in Galicia," Petroleum Review, June 19, 1909, 357-358, 366.

38 William Johnston, The Austrian Mind (Berkeley, Calif., 1972), 48, 50.

${ }^{39}$ Franz Baltzarek, "Franz Klein als Wirtschafts- und Sozialpolitiker," in Herbert Hofmeister, ed., Forschungsband Franz Klein: Leben und Wirken (Vienna, 1988), 173.

${ }^{40}$ David Gerber, "The Origins of European Competition Law in Fin-de-Siècle Austria," American Journal of Legal History 36, no. 4 (October 1992): 414.

41 "Amtserinnerung betreffend die von der Regierung zum Schutze der heimischen Petroleumindustrie zu ergreifenden Massnahmen,” June 18, 1910, ÖStA, Ministerrats-Präsidium [hereafter MP], 2462 . 
zations. The minister of finance, Leon Ritter von Biliński, set taxation laws that applied to oil production, refining, sales, and consumption. The minister for Galicia, Władysław Ritter von Dułęba, was responsible for representing the interests of the empire's only significant oil-producing province. A conference held at the Finance Ministry on June 8, 1910, brought them all together to consider "drastic measures for the protection of the home petroleum industry." ${ }^{42}$ Molding a lex specialis that would simultaneously punish Standard's cronies and leave everyone else unharmed required all the creative talents that the administration could muster. Discussion quickly focused on a confidential proposed revision of petroleum freight tariff policy that had been circulated by Railway Minister Wrba. Wrba's proposal included new conditions determining eligibility for long-established discounts on shipping petroleum products that neither Vacuum nor any other refinery under the influence of Standard could possibly satisfy. ${ }^{43}$ The Railway Ministry, boasting that "at the time of the existence of the private railways, such a measure would have been impossible," may have been motivated in part by a desire to demonstrate its own usefulness. ${ }^{44}$ Other ministries were at a loss to suggest better alternatives, and given the urgent need to "free Austrian refineries from the pressure of American competition as much as possible," they followed Wrba's plan to manipulate railway tariffs. ${ }^{45}$ Without mentioning Standard or Vacuum by name, the new regulations were designed to drive Vacuum and its allied refineries out of business.

In only two weeks, new tariff rules increased freight costs for the targeted refineries by 70 percent and more. ${ }^{46}$ Vacuum estimated that the higher prices alone would cost it $\$ 1,000$ (U.S.) per day, and the Railway Ministry predicted that "given such extraordinary freight increases, the named refiners will hardly be in a position to maintain operations." 47 But the discriminatory measures did not end there. In mid-June, the Railway Ministry canceled the hauling contract that allowed Vacuum to use tank cars on state railways, as well as contracts allowing the company to connect its storage tanks with the government-owned filling pipes required to load crude oil into tank cars. Most crippling to Vacuum's daily operations, on September 10, the Railway Ministry put into effect the cancellation of a contract that allowed Vacuum to use a switch connection between its refinery at Dzieditz/Dziedzice and the railway. ${ }^{48}$ The refinery was then effectively cut off from the rest of the world. Ironically, Standard Oil faced elimination from the Austrian market thanks to discriminatory limits on access to railways.

The Petroleum War was possible only because of the nineteenth century's trans-

42 Weiss and Hooker to Kerens, NARA, RG 59, Box 4461, 363.115 V 13.

43 “Tarifmaßnahmen zur Unterstützung der heimischen Petroleumindustrie," May 30, 1910, ÖStA, MföA, F664, Z634.

44 "Antrag, betreffend teilweise Aenderung der Petroleumtarife der k.k. österr. Staatsbahnen," May 29, 1910, ÖStA, MföA, F664, Z634. The Railway Ministry was created in 1896. Walter Goldinger, "Die Zentralverwaltung in Cisleithanien-Die zivile gemeinsame Zentralverwaltung," in Adam Wandruszka and Peter Urbanitsch, eds., Die Habsburgermonarchie, 1848-1918, vol. 2: Verwaltung und Rechtswesen (Vienna, 1975), 146.

${ }^{45}$ Ritt's and Weiskirchner's responses to Bienerth's request for position statements, June 9 and 10 , 1910, ÖStA, MP, Z2411.

46 "Resumé über die Besprechungen des Ministerialtarifkomitees vom 1. und 6. Juni 1910, betreffend Maßnahmen zur Unterstützung der heimischen Petroleumindustrie,” ÖStA, MföA, F664, Z634.

47 “Antrag, betreffend teilweise Aenderung der Petroleumtarife der k.k. österr. Staatsbahnen," ibid.

48 Charles Everest to Knox, New York, October 26, 1910, NARA, RG 59, Box 4462, 363.115 V 13/37. 
portation revolution: Standard's competitiveness in Europe was dependent on steamships; Austria's ability to fight Standard at home and compete with it abroad was dependent on railroads. While historians and economists are rightly inclined to trumpet the many accomplishments of the railroad, this episode reminds us that railroads were also a tool for the uneven dispensation of economic power-not just by virtue of their existence in some places and not in others, but also by virtue of their manipulation. The irony of a story about discriminatory railroad pricing used against, rather than by, Standard was appreciated by outside observers, who, at a distance, were able to derive a measure of amusement from the whole conflict. The Times of London noted that Austria applied "methods of administrative chicanery and railway discrimination strikingly similar to those which made the name of the Standard Oil Company a byword in the United States." Under the motto that imitation is the highest form of flattery, it went on to observe: "The tactics of the Austrian authorities are as indefensible, or as defensible, as are those of the Standard Oil Company; but, as a sense of humour is not always an asset in business and diplomacy," the State Department had "made diplomatic representations to the Austro-Hungarian Foreign Office on behalf of the American ... interests affected by Austrian flattery of Mr. Rockefeller." ${ }^{49}$ The Times was alluding to Rockefeller's own record of having "expanded his position in refining by 'raising rivals' costs.' " 50 It was not by offering refined products at impossibly low prices that Rockefeller was able to secure Standard's dominance in the domestic oil industry, but rather by colluding with those railroads that together controlled the transportation of crude oil from and to points of production and refining. According to economists Elizabeth Granitz and Benjamin Klein, "Standard and the railroads, by cooperating with one another, did something jointly that neither of them could do separately-they created a monopoly." Their analysis shows "that it was petroleum transportation, not refining, that was monopolized and that the profits earned by Standard in refining should be thought of as merely a share of the monopoly profits from the transportation cartel." 51 Austria's best model in using railroads to hamstring Vacuum Oil was Standard Oil itself.

Rockefeller's infamous octopus, the Standard Oil Trust, was one of the most powerful corporations in the world at the time, but it was also surrounded by enemies. Ida Tarbell's denunciation of Rockefeller had already been published in multiple editions, and was available in bookstores across the United States. ${ }^{52}$ In Washington, members of Congress had been enacting legislation directed at curbing Standard's business operations since 1906, and their antipathy showed no sign of abating; in addition, dozens of individual states had initiated lawsuits against the Trust. ${ }^{53}$ The federal government had filed a suit to dissolve the company under the

49 "Hungarian Finance: The Failure of the Loan Negotiations," Times (London), September 15, $1910,5$.

${ }_{50}$ Elizabeth Granitz and Benjamin Klein, "Monopolization by 'Raising Rivals' Costs': The Standard Oil Case," Journal of Law and Economics 39, no. 1 (April 1996): 23.

51 Ibid., 24, 27; Johnson, "Public Policy and Concentration in the Petroleum Industry, 1870-1911," in Oil's First Century: Papers Given at the Centennial Seminar on the History of the Petroleum Industry, Harvard Business School, November 13-14, 1959 (Cambridge, Mass., 1960), 47.

52 Ida Tarbell, The History of the Standard Oil Company (New York, 1904).

${ }^{53}$ Lawsuits were pending in Kentucky, Tennessee, Kansas, Missouri, West Virginia, Connecticut, Ohio, Arkansas, Maryland, Texas, and Oklahoma. Hidy and Hidy, Pioneering in Big Business, 674-676, 


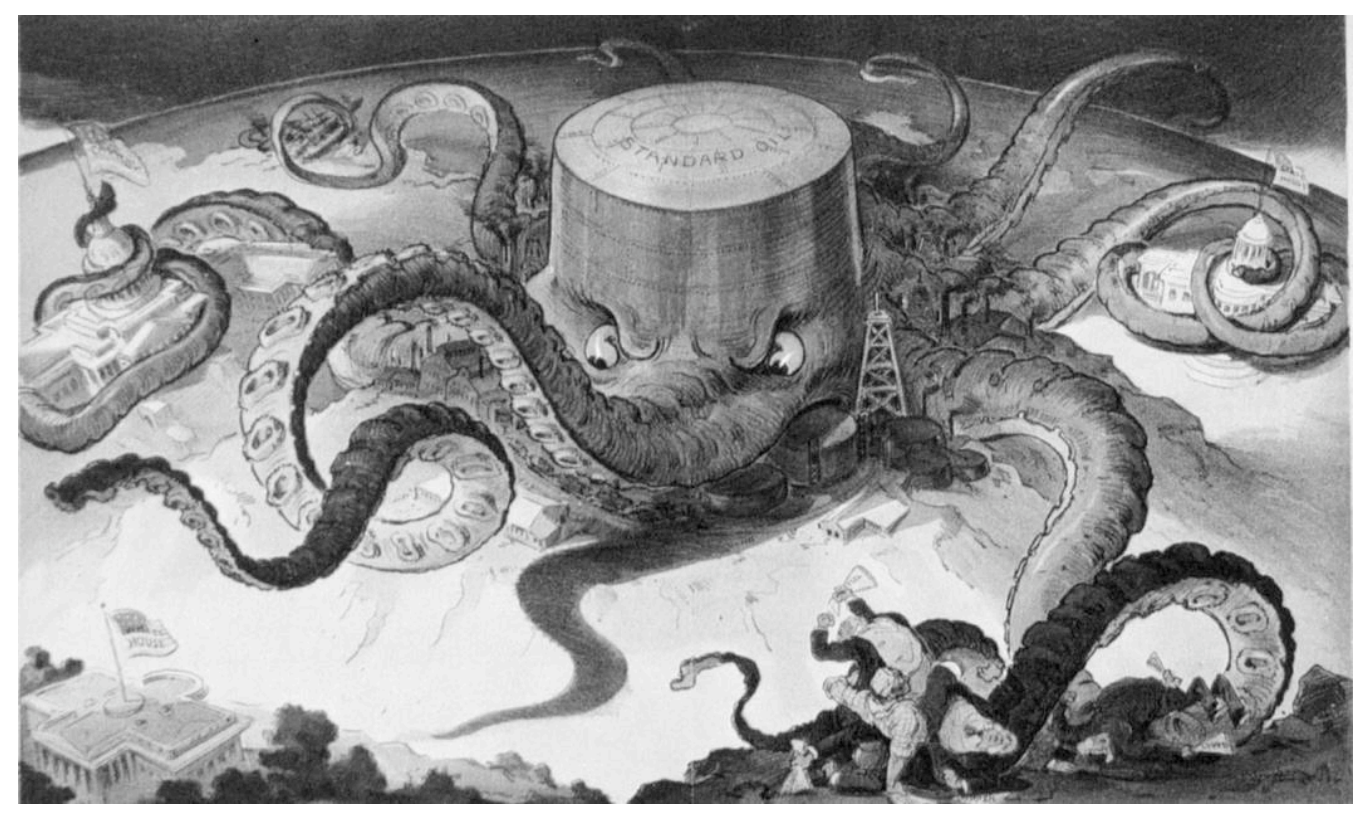

Figure 1: "Next!" This cartoon by Udo J. Keppler, which was published in Puck on September 7, 1904, depicts Standard Oil as an octopus whose tentacles have already grabbed the steel, copper, and shipping industries, an unidentified statehouse, and the U.S. Capitol; another tentacle is poised to capture the White House. The last three tentacles stretch out across the Atlantic, presumably toward Europe. Color lithograph, Library of Congress Prints and Photographs Division Washington, D.C., LC-USZC4-435 (color film copy transparency).

terms of the Sherman Antitrust Act in November of 1906 that would surpass in documentation and expense anything previously seen in the United States. ${ }^{54}$ The Trust's last hope of avoiding dissolution was put to the test when arguments before the Supreme Court began on March 14, 1910.55 All of America-the public, state and federal government, state and circuit courts—had lost patience with the incomparable strength that Standard Oil's predatory practices, sophisticated networks, deep pockets, and general business acumen had allowed it to build up across the country. It was this perceived tension between the U.S. government and Standard Oil that convinced Austrian officials that they could take action against Standard's Austrian subsidiary, Vacuum Oil, with impunity. But when the Austrian imperial government assumed that discriminatory measures taken against Standard Oil on foreign soil would be welcome to a government prosecuting Standard at home, it was gravely mistaken. Far from greeting the Austrian measures as assistance in punishing a greedy multinational corporation, the State Department opposed them as unfair attacks on an important U.S. business interest.

In the context of battles with larger rivals, the asymmetric conflict between the Standard Oil Trust and Austrian refiners might well have been dismissed by Standard

684; Allan Nevins, Study in Power: John D. Rockefeller, Industrialist and Philanthropist, 2 vols. (New York, 1953), 2: 356.

${ }^{54}$ Chernow, Titan, 538. Before it even reached the Supreme Court, the case had cost an estimated $\$ 4$ million and produced a court record of approximately 11.5 million words. "Millions Spent in Oil Prosecution," New York Times, January 16, 1909, 14.

55 "Oil Fight Begins in Supreme Court," New York Times, March 15, 1910, 3. 
as "trifling." Standard did not, however, simply shut down its Austrian operations in disgust and move elsewhere. On the contrary, Vacuum responded to the discriminatory measures by calling on another government for support: that of the majority of its stockholders, the United States. It did this not by appealing directly to the U.S. ambassador in Vienna, but rather by turning to Standard Oil and its chief diplomat, William Herbert Libby. Libby, who had worked for Standard Oil for thirty-two years and had represented its foreign interests since he was first sent to the Far East in 1882, barraged the secretary of state with letters demanding that Vacuum's interests be taken up by the U.S. government. ${ }^{56}$ According to Ralph and Muriel Hidy, "No agent of Standard Oil journeyed further, saw more prominent people, or had a greater influence" than Libby. He was "a personable and cultivated representative, an experienced merchant of oil, an astute observer of trade conditions, an able judge of men, and a tenacious negotiator." 57 Much of the diplomatic language that the State Department used in its communications with Austria-Hungary throughout this dispute actually originated with Libby.

Libby's success in galvanizing the State Department into action demonstrates that even though the breakup of the Trust was less than a year away, the U.S. government was not indifferent to Standard's treatment abroad. A German newspaper warned that the Viennese suggestion "that the American government does not appear to attend to Vacuum Oil Co., because 'the hatred of Standard Oil Co. in America is so great that no one in Washington wants to lift a finger to help it,' directly contradicts the real facts, and such an erroneous perception of circumstances could lead to a very dangerous tight-rope dance." 58 Since the attack on Standard within Austria took place in the context of presumed U.S. indifference to the company's fate, it reminds us that the breakup of the Trust-anticipated for several years before it was formally mandated by the Supreme Court on May 15, 1911-had repercussions beyond the United States: America's business was everybody's business. ${ }^{59}$ Reconnecting the dissolution of the Standard Oil Trust with the treatment of Standard Oil outside the U.S. can help us meet Thomas Bender's call to "imagine an American historical narrative that situates the United States more fully in its larger transnational and intercultural global context." 60 By pursuing its interests in Austria, Standard Oil was not only protecting its market share there, but also demonstrating that the dissolution of the Trust at home should not be interpreted as Standard's vul-

56 Correspondence between Libby and the secretary of state from June 20, 1910, until the spring of 1912 in NARA, RG 59, Boxes 4461 and 4462. Hidy and Hidy, Pioneering in Big Business, 137. Libby continued to lobby on behalf of Vacuum Oil in 1911 after the breakup of the Trust, supporting the claim that "co-ordination of the activities of [the successors to the Trust] continued through common ownership and by virtue of long-established relationships which no legal decree could destroy overnight." Arthur Johnson, "Continuity and Change in Government-Business Relations," in John Braeman, Robert Bremner, and Everett Walters, eds., Change and Continuity in Twentieth-Century America (Columbus, Ohio, 1965), 201.

57 Hidy and Hidy, Pioneering in Big Business, 136.

58 Dmd 14, f. 44, L’vivs'ka Naukova Biblioteka im. Stefanyka, L'viv, Ukraine.

59 "Standard Oil Company Must Dissolve in 6 Months," New York Times, May 16, 1911, 1. For greater reflection on "the integration of the United States into the capitalist world economy" and the opportunities it affords transnational history, see Ian Tyrell, "American Exceptionalism in an Age of International History," American Historical Review 96, no. 4 (October 1991): 1044-1050.

60 Thomas Bender, "Introduction: Historians, the Nation, and the Plenitude of Narratives," in Bender, ed., Rethinking American History in a Global Age (Berkeley, Calif., 2002), 10. 
nerability abroad. Ironically, however, this "transnational" context highlights the great relevance of "nationalist" thinking and state support.

To move the State Department to action, Libby argued that more than Vacuum's business interest was at stake. Vacuum was "the most important American enterprise in that Empire," and other American businessmen would watch its fate closely. ${ }^{61}$ U.S. officials agreed that Vacuum's vulnerability to Austrian persecution would set a perilous example. Only two days after it received Libby's initial complaint, the State Department's Division of Near Eastern Affairs received a cablegram from the U.S. consul general in Vienna, Charles Harvey Denby, Jr. ${ }^{62}$ In the inelegant language of telegraph communications, Denby warned that "if equality of opportunity American capital in this important matter is not maintained precedent will be established dangerous other American interests." The Austrians, he continued, assumed that their actions "towards this American group ... will be agreeable the Government of the United States."63 Assistant Secretary of State Huntington Wilson responded by instructing Ambassador Richard C. Kerens to "make immediate representation to the Austro-Hungarian government requesting that the proposed repressive measures be suspended"- - a proposal very much in keeping with Kerens's personal inclination. ${ }^{64}$ Standard could hardly have hoped for a more sympathetic representative in Vienna.

Kerens had a long history in both business and politics. ${ }^{65} \mathrm{He}$ was a board member of Edward Doheny's Mexican Petroleum Company and had spent ten years on the Continental Railway Commission; Doheny's biographer called him a stellar example of "the rising class of western businessmen." 66 He served on the Republican National Committee for decades. ${ }^{67}$ In return for his loyalty, President William Howard Taft appointed him to a "diplomatic post of the first rank" - ambassador to Austria-Hungary-shortly after his inauguration in 1909.68 Standard had in Kerens a staunch Republican and a lifelong defender of the spirit of enterprise who, in his many years in business, had relied more than once on personal connections with well-placed politicians_-and with representatives of Standard Oil. ${ }^{69}$ But Kerens's reliance on

61 The phrase originates in a letter from Libby to Knox (October 26, 1910) and was adopted by the Division of Near Eastern Affairs (October 31, 1910). NARA, RG 59, Box 4462, 363.113 V 13/37.

62 Denby had been transferred to the U.S. consulate in Vienna in 1909 from Shanghai, where he had been U.S. consul general.

${ }^{63}$ Denby to Knox, June 18, 1910, NARA, RG 59, Box 4461, 25024/1.

${ }^{64}$ Huntington Wilson to Kerens, Washington, D.C., June 22, 1910, ibid.

${ }^{65}$ Francis Weber, Encyclopedia of California's Catholic Heritage, 1769-1999 (Mission Hills, Calif., 2001), 973

66 John A. Caruso, “The Pan American Railway," Hispanic American Historical Review 31, no. 4 (November 1951): 613; Dan La Botz, Edward L. Doheny: Petroleum, Power, and Politics in the United States and Mexico (New York, 1991), 14. Kerens was a principal stockholder and director of the InterMountain Oil Company, capitalized at \$10 million in 1902. "To Develop Oil Lands in Wyoming," New York Times, September 7, 1901, 12.

67 Kerens worked tirelessly on the presidential campaigns of both Benjamin Harrison and William Howard Taft. His senatorial campaigns in Missouri were hindered by suspicion among his fellow Republicans of his "militant" Catholicism. Correspondence between Thomas Benson Whitledge and Kerens, Edward Rozier, and Benjamin Cahoon, 1874-1908, Thomas Benson Whitledge Papers, R276, Western Historical Manuscript Collection, University of Missouri-Rolla. Kerens was a "militant champion of strict interpretation of the laws of the Roman Catholic Church throughout his life." "Is Divorce Good Behavior? Court Must Settle Point," New York Times, October 13, 1929, M4.

68 "Many Plums to Give," New York Times, November 16, 1909, 5.

${ }^{69}$ For example, Kerens called on Russell Harrison to intervene with the secretary of war on behalf of one of his companies. Kerens to Harrison, St. Louis, Mo., August 15, 1891, Harrison, R. B. Mss., Manuscripts Department, Lilly Library, Indiana University, Bloomington. In 1902, Kerens recom- 
friendly and informal relationships to get favorable results did not stand him in good stead within the Austrian diplomatic environment. ${ }^{70}$ Although the Viennese post may have been a pleasant one thanks to the imperial capital's social and cultural standing, Austro-American diplomatic relations were not a priority for either country. ${ }^{71}$ Nor was Austria-Hungary willing to bend protocol to suit Kerens. Diplomatic procedure mandated that all his correspondence go through the Foreign Office. Although Vacuum was regularly referred to as an "American" company in internal ministerial correspondence, Foreign Minister Aerenthal rebuffed Kerens's efforts to broker an agreement by repeating ad nauseam that Vacuum was a domestic company, and thus relations between Austria and Vacuum did not fall under the purview of a foreign ambassador-or of the foreign minister. Even the U.S. State Department's Bureau of Trade Relations had to admit internally that "this policy is purely a domestic affair and is none of the business of the United States."72 Nevertheless, while Aerenthal appeared to be an impenetrable wall allowing no intercourse between the U.S. embassy and his own government, he diligently forwarded Kerens's increasingly impatient appeals to Prime Minister Bienerth. ${ }^{73}$ Bienerth in turn forwarded them to the relevant Austrian ministries (Commerce, Finance, Public Works, Railways, and Galicia), and it was Minister of Commerce Weiskirchner, in consul-

mended to Doheny that they "sell a half interest" of the Mexican Petroleum Company either to Standard or to an affiliate. Kerens expected to be able to "get Mr. [Henry Clay] Pierce to go down there [Mexico] with me" to share in his "greatest delight . . good hunting." Kerens to Doheny, Chicago, July 20, 1902, Archival Center, Archdiocese of Los Angeles, Papers of Carrie Estelle and Edward L. Doheny. Kerens peppered his correspondence with phrases such as "I will, of course, stand by the friends who have stood by me" and "I will help in any way I can, and stand squarely by my friends." Kerens to Whitledge, October 6, 1896, and February 23, 1903, Whitledge Papers.

70 This is not to say that personalities and individual relationships were insignificant. J. Schwegel, an Austrian imperial consul for Manitoba, Saskatchewan, Alberta, and British Columbia in Winnipeg, privately offered a possible explanation to Kerens in the summer of 1911: "I had the impression that a great deal of ill feeling in this affair on the part of our Government has been caused by the insolent manner in which some of the representatives of the American Company have been behaving, thus making it difficult for our Government to give in, no matter how peacefully inclined at heart." Kerens to Wilson, Elkins, W.Va., August 28, 1911, NARA, RG 59, Box 4462, 363.115 V 13/84; J. Schwegel to Kerens, Bolzano, July 9, 1911, ibid.

${ }^{71}$ Almost all of the press coverage of Ambassador Kerens in the United States revolved around social events, such as the début, and later the engagement, of his daughter Gladys. "Fashion's Fads and Fancies," Washington Post, August 1, 1910, 7. Diplomatic relations between Austria-Hungary and the United States had been temperate since the revolutions of 1848; the two states interacted only to resolve minor disagreements over immigration or the filling of diplomatic posts. Harry Hanak, "Die Einstellung Grossbritanniens und der Vereinigten Staaten zu Österreich(-Ungarn)," in Wandruszka and Urbanitsch, Die Habsburgermonarchie, 1848-1918, vol. 6, pt. 2: Die Habsburgermonarchie im System der Internationalen Beziehungen (Vienna, 1993), 557. The most common source of conflicts was whether it was appropriate for naturalized U.S. citizens who had previously been citizens of Austria-Hungary to be compelled to fulfill outstanding obligations to serve in the Austro-Hungarian military if they returned to Austria-Hungary. Rudolf Agstner has surmised that the monthly reports sent by consuls in the $1890 \mathrm{~s}$ "probably ended up unread in a drawer." Agstner, "From Apalachicola to Wilkes-Barre: Austria(-Hungary) and Its Consulates in the United States of America, 1820-1917," Austrian History Yearbook 38 (2006): 167. Nicole Phelps argues that nearly all diplomatic communication between the U.S. and Austria-Hungary can be grouped into one of three categories: conflicts over diplomatic ceremony, disputes over trade (primarily over tariffs), and migration-related issues. Phelps, "Sovereignty, Citizenship, and the New Liberal Order: US-Habsburg Relations and the Transformation of International Politics, 18801924" (Ph.D. diss., University of Minnesota, 2008).

72 Charles Pepper, "Standard Oil Case in Austria-Hungary," stamped as received August 20, 1910, NARA, RG 59, Box 4461, 25024/21.

73 Aerenthal to Bienerth, November 3, 1910, ÖStA, Finanzministerium [hereafter FM], Präs. Z2111. 
tation with a Standing Interministerial Committee for Petroleum Affairs created to handle this affair, who drafted the responses that Aerenthal would render into more diplomatic language and then send on to Kerens. ${ }^{74}$ Because of this insistence that no direct communication between the U.S. ambassador and the relevant Austrian ministries could take place, each side spent considerable energy trying to divine the "true" positions of decision-makers in the other country. And throughout the dispute, the State Department found itself relying and acting on information gathered and interpreted by representatives of Standard Oil.

Just AS KeREnS wAS SURPRISED By Austria-Hungary's refusal to grant him any jurisdiction over what it argued was a purely domestic matter, so, too, was the AustroHungarian Foreign Ministry shocked to discover that the U.S. government felt any sense of obligation to protect Standard Oil. Was it not true that, as a governmentfriendly newspaper noted, "in the Union itself, a war of extermination is being waged against the tyrannous supremacy of the oil trust"? ${ }^{75}$ Heinrich Ritter Löwenthal von Linau, legation counselor in the Austro-Hungarian embassy in Washington, D.C., noted in a confidential letter to Aerenthal, "It seems to me self-evident, that the higher powers in the current federal government, in so far as they are concerned with such matters at all, allow themselves to be led by the effort to accord the same powerful Trust, against which they, in the real or imagined electoral interest of the Republican Party, claim to proceed with all the strength of the law in their own country, the greatest possible signs of affection on foreign soil."76 From the perspective of the Taft administration, the overlying principle of the case was not the fight against Standard's monopoly within the United States, but rather the administration's support of U.S. businesses abroad, a policy known to its critics as "Dollar Diplomacy."

President Taft boasted in 1909 that his Republican administration was "lending all proper support to legitimate and beneficial American enterprises in foreign countries," and that the State Department would soon reveal itself to be "a thoroughly efficient instrument in the furtherance of foreign trade and of American interest abroad."77 Taft's proclaimed advocacy of U.S. businesses overseas was taken as a

74 "Regierungsmassnahmen gegen die Vacuum Oil Company," July 23, 1910, ÖStA, MföA, F664, Z874-XIV, ex. 1910; or "Neuerliche Intervention der amerikanischen Botschaft in Angelegenheit der Vacuum Oil Company," November 21, 1910, ÖStA, FM, 85817. Other examples include FM, Z76227, October 19, 1910, and ÖStA, MföA, F664, Z981.

75 "Die Vorgänge in der Petroleumindustrie," Neues Wiener Tagblatt (Vienna), October 9, 1910, NARA, RG 59, Box 4462, 363.113 V 13/36.

76 Heinrich Löwenthal von Linau to Aerenthal, Washington, D.C., November 10, 1911, Haus-, Hofund Staatsarchiv, Vienna, Austria [hereafter HHStA], Ministerium des Äußern [hereafter MdA], Administrative Registratur [hereafter AR], F97/10, Handelsartikel-Petroleum, folder 97 Petroleum 69c.

77 Wilkins, The Emergence of Multinational Enterprise, 74. Rockefeller had endorsed Taft in the 1908 election: "He is not a man, I judge, ... to impede the return of prosperity by advocating measures subversive of industrial progress." Chernow, Titan, 553. This attitude was politically contingent, and not a constant feature of U.S. foreign policy. George Gibb and Evelyn Knowlton insist that "at no time in the 1912-1917 period was effective diplomatic action taken to back Jersey Standard in its efforts to acquire oil reserves in the face of determined resistance from strong competitors and strong foreign governments," which reflects a change in U.S. foreign policy once Woodrow Wilson replaced Taft as president. The Wilson administration's opposition to "economic imperialism" and its belief that the U.S. government was duty-bound to "free [foreign, but particularly Latin American] countries of foreign 
matter of policy by the secretary of state, Philander Chase Knox, who, according to his assistant secretary of state, Huntington Wilson, "gave a new definiteness, intelligibility and practicalness to American diplomacy."78 Nevertheless, the State Department weighed the merits of individual cases carefully before "drawing off for the protection of a foreign enterprise a measure of the national prestige and power entrusted by the people to its care."79 And, despite Consul General Denby's urgings in June of 1910 and the Bureau of Trade Relations' eagerness to show "that we do not neglect our commercial interests abroad whatever legal action we may feel it desirable to take at home in regard to some of them," the State Department was slow to consider any action beyond diplomatic appeals to Foreign Minister Aerenthal. ${ }^{80}$ So, although Charles Pepper of the Bureau of Trade Relations argued in August that "a growing tendency has been shown on the part of foreign governments to take advantage of domestic affairs of this kind [i.e., the breakup of the Trust] to injure American enterprise abroad and it is well at every opportunity to let them understand that the United States will not tolerate such a course," Assistant Secretary of State Wilson replied laconically: "Pretty small real American interest and pretty weak case-so far shown. I think we should go not too zealously." 81 Wilson's main concern was to ensure that the share of European oil markets held by companies shipping oil from the United States did not decrease-not to guarantee that Vacuum could maintain its business operations within Austria-Hungary. Libby had presented Standard's own goal as "to safeguard to the fullest extent practicable the supremacy of American Petroleum" in Europe-but would this goal be served by defending Vacuum Oil? ${ }^{82}$ To negotiate a deal that would help Vacuum within Austria but hurt Standard in the much larger German market, for example, appeared senseless: "There would not be much advantage," Pepper noted, "in helping the Vacuum Oil Company to settle the controversy on a basis which would result in the Standard Oil Company decreasing its shipments from the United States to the German and other markets." 83 The State Department politely forwarded Libby's stream of protests to Kerens, but did nothing throughout the summer to raise the stakes.

In October 1910, however, veteran State Department official Alvey Augustus Adee ominously cabled Kerens that he hoped for a speedy "friendly solution of this controversy" so that "it will not be necessary to proceed to measures of trade retaliation which otherwise this Government would undoubtedly be bound to sup-

\footnotetext{
domination" made it largely unwilling to use the State Department or the U.S. military as a tool to advance U.S. business abroad. George Sweet Gibb and Evelyn H. Knowlton, The Resurgent Years, 19111927 (New York, 1956), 107; Wilkins, The Emergence of Multinational Enterprise, 166. According to Günter Bischof, on the eve of the First World War, "the question was only whether the USA would ever intervene in European affairs in order to secure its export markets." Bischof, "Das amerikanische Jahrhundert: Europas Niedergang-Amerikas Aufstieg," Zeitgeschichte 28 (March-April 2001): 75-95. This incident suggests that the State Department had already determined that it should, but that it had difficulty finding the means to act on that determination.

${ }^{78}$ Huntington Wilson, "The Relation of Government to Foreign Investment," Annals of the American Academy of Political and Social Science 68 (November 1916): 299.

79 Ibid., 300.

80 Pepper to Wilson, July 14, 1910, NARA, RG 59, Box 4461, 25024/7.

${ }^{81}$ Pepper, "Standard Oil Case in Austria-Hungary," and Wilson's penciled marginalia on a memo from Pepper to Wilson, August 19, 1910, NARA, RG 59, Box 4461, 25024/21.

${ }^{82}$ Libby to Knox, New York, June 6, 1911, ibid., 363.115 V 13/80.

83 Pepper, "Standard Oil Case in Austria-Hungary," 5.
} 
port." 84 The change of attitude that produced this telegram can be explained only by reference to developments not in Washington or Vienna, but rather in France. At the same time that the Austrian government had targeted Vacuum, it had taken the same discriminatory measures against another company rumored to be closely allied with the Americans: the Petroleum Licht und Kraft Gesellschaft (Petroleum Light and Power Company), better known as Limanowa, after the Galician town where its refinery was located. Limanowa's organization paralleled Vacuum's-although it was officially incorporated in Austria (hence the German name), its stockholders were French. It had been founded in 1904 by Desmarais Frères, one of France's most important petroleum refiners, after an increase in French import duties on foreign crude made it more profitable to refine near the source. ${ }^{85}$ Allegations of collusion between Vacuum and Limanowa were reported widely in both Austrian government documents and the international press. For example, an article in the London Times asserted, "This company [Limanowa], in which some $£ 500,000$ of French capital are invested . . . is understood to have been working in some kind of unconfessed relationship with the Austrian branch of the Standard Oil Company of America, known as the Vacuum Oil Company."86

Diplomatic relations with France, unlike those with the United States, were a high priority for Austria-Hungary-and they were already strained. Ever since Austria-Hungary had annexed Bosnia-Herzegovina in 1908, French public opinion and French diplomacy had been united in anticipation of a coming confrontation with the Habsburg monarchy. ${ }^{87}$ But Austria-Hungary's Foreign Ministry saw no reason why its dispute with Vacuum should cause tension with France. Austria's government ministers were convinced that Limanowa was merely a puppet of Vacuum, and ultimately of Standard, and that it therefore was an agent of Standard's interest, not France's. Back in June, the minister of foreign affairs had instructed Albert Count Nemes, minister plenipotentiary at the monarchy's embassy in Paris, to explain to the French government that "France's interests not only are not injured by our measures [against Limanowa], but are, rather, identical to ours, since France certainly has no reason to support the creation of a global monopoly whose impact would affect its economic life as much as ours." 88 Limanowa's directors did not agree. Once again, how to assess the "true" national affiliation of a corporation became a matter of bitter dispute. Did Limanowa's board and shareholders make it "French"? Did its incorporation in Vienna and its refinery's location make it Austrian? Did its reported alliance with Standard make it an American imposter?

The French press was not concerned with such sophistry. Throughout the late summer, French newspapers were abuzz with a campaign to discredit Austria and

${ }^{84}$ Alvey Augustus Adee to Kerens, Washington, D.C., October 12, 1910, NARA, RG 59, Box 4462, $363.115 \mathrm{~V} \mathrm{13/32.}$

85 Smith, Emergence of Modern Business, 425. It had 12 million crowns in capital, a 150,000-toncapacity refinery in Limanowa, and reservoirs in Borysław, Berlin, Wrocław/Breslau, Leipzig, and Düsseldorf. "Petroleum Licht und Kraft Gesellschaft à Vienne," August 1919, AHCL, DEEF, 30167, Note no. 4802; "Stés pétrolifères en Galicie," AHCL, DEEF, 22085, folder MB3.

86 "Hungarian Finance."

87 Jean Bérenger, "Die Österreichpolitik Frankreichs von 1848 bis 1918," in Wandruszka and Urbanitsch, Die Habsburgermonarchie im System der Internationalen Beziehungen, 535.

88 Aerenthal to Albert Count Nemes, June 21, 1910, HHStA, MdA, AR, F97/10, HandelsartikelPetroleum, folder 97 Petroleum 69a, Z38376/2191. 
to associate Limanowa's maltreatment with a Hungarian loan that France was poised to underwrite. ${ }^{89}$ In an article tellingly titled "Certain Countries Too Often Forget That French Capital Is One of the Elements of Our Power," the outraged journalists at Le Matin protested: "It is impossible to comprehend how French capital could provide prosperity in a country where French enterprises are harassed in this manner." 90 Le Gaulois was equally hostile, claiming that "The [Austrian] government . . . should know that, financially and commercially, we have all the means to respond to the unjustifiable provocation to which our national interests are subjected." 91 L'Information charged, "The measure was obviously brutal and of such a method that it constitutes a flagrant attack on liberty of commerce and the rights of nations."92 Although the Austrian ambassador in Paris dismissed the rumblings of the press as "an attempt to exploit a presented opportunity to squeeze out subventions," the French government soon followed through. ${ }^{93}$ In mid-September, the Hungarian loan negotiations, which Hungarian finance minister László Lukács had assumed were sure to end favorably, failed. ${ }^{94}$ Limanowa's director warned the Ministry of Finance that he expected punitive tariffs on Austrian petroleum products imported into France to go into effect no later than October 26, unless Limanowa's eligibility for reduced crude oil freight charges, their use of the filling stands in Borysław, and their access to railway cars for the transport of refined products were restored. ${ }^{95}$

This proved to be an effective tactic, and even while punitive measures against Vacuum continued unabated, by November the Standing Interministerial Committee for Petroleum Affairs thought that it was time to ease off on Limanowa without losing face. ${ }^{96}$ Austria-Hungary was forced to admit that it had miscalculated on two counts. Not only did France steadfastly refuse to acknowledge that its interests and Austria-Hungary's were "identical," but the Austrian petroleum refiners that the

89 Analyses of and clippings from the French press are in ÖStA, FM, Z62775, 69236, 69525, 71345, and 71346, and in NARA, RG 59, Box 4462. The Austro-Hungarian Ministry of Foreign Affairs collected newspaper clippings on the "guerre du pétrole" from the following papers: L'Action Française, L'Agence Fournier, L'Aurore, Côte de la Bourse et de la Banque, L'Écho de Paris, L'Éclair, Le Figaro, Financial News, Le Gaulois, Gil Blas, L'Information, Journal des Débats, Journal Officiel, La Liberté, Paris-Journal, Le Petit Parisien, La Petite République, Le Radical, La Reforme Économique, La République Française, Le Temps. HHStA, MdA, AR, F97/10, Handelsartikel-Petroleum, folder 97 Petroleum 69b.

90 "On oublie trop dans certains pays que l'épargne française est un des elements de notre puissance," Le Matin, September 17, 1910, clipping in “Ausschnitte Pariser Blätter über die Press-Kampagne gegen Oestereich-Ungarn," September 26, 1910, ÖSta, FM, Z71345. Strictly speaking, the Austrian government persecuting Vacuum was completely separate from the Hungarian government seeking the loan. Following the reorganization of the empire into two separate parts in 1867, the finances of Austria and Hungary were connected only when it came to paying for the military, the foreign service, and the administration of Bosnia-Herzegovina.

${ }_{91}$ "Une industrie française: L'Affaire de la Limanowa," Le Gaulois, September 17, 1910, clipping in ÖStA, FM, Z71345.

92 L'Information, October 7, 1910, clipping in HHStA, MdÄ, AR, F97/10, Handelsartikel-Petroleum, folder 97 Petroleum 69b. The clipping is labeled only L'Information, but this is almost certainly the French daily L'Information financière, économique, et politique, which was published in Paris from 1899 until 1985.

${ }^{93}$ K. u. k. Embassy in Paris, Report no. 17 G, August 6, 1910, ÖStA, FM, Z62775.

94 "Hungarian Finance."

95 Report of October 24, 1910, ÖStA, MP, 2411.

96 "Beseitigung der den Betrieb der Raffinerie der Petroleum Licht- und Kraftgesellschaft behindernden Maßnahmen," November 5, 1910, ÖStA, MföA, Präs Z1989, ex. 1910. It was essential that any agreement not amount to a "humiliating declaration" on Austria's part. Biliński to Aerenthal, November 10, 1910, ÖStA, FM, Präs. Z2111. 
government was ostensibly trying to protect were unwilling to cooperate with one another-or with their government. The whole premise of the Austrian plan was that punitive measures would force Vacuum (and Limanowa) to accept the price spectrum and market share allocation determined by the block of petroleum refiners who participated in OLEX. When that same block of refiners collapsed in October, the government had an opportunity to declare that it would change its policy based on a transformed domestic situation, rather than because of French pressure. ${ }^{97}$ On November 3, 1910, representatives of Limanowa signed a declaration promising not to cooperate with Vacuum in any way that could help the company evade government measures taken against it, and pledging to work together with the other domestic refineries to regulate the sale of petroleum products in the Austrian and French markets. In a move that reflected Austria's acknowledgment that French and American accusations of "chicanery" might have some merit, Limanowa also agreed to refrain from suing the Austrian administration over the "procedures" in effect up to October 31, $1910 .{ }^{98}$ Despite the resistance of leading Austrian refiners, which threatened to stymie further negotiations, lay off workers, and close down if the deal involved conceding a decrease in Austrian refined oil exports to France, the Railway Ministry rescinded the measures against Limanowa. ${ }^{99}$

The French press magnanimously blamed the whole affair on the "excess of zeal of subaltern employees." 100 That the agreement amounted to little more than a complete capitulation on Austria's part can be surmised by the government's response to a letter sent by a group of major Galician refiners to Dułęba, the minister for Galicia, complaining of Limanowa's resumption of cutthroat tactics (such as dumping refined products in Galicia and upper Hungary). Although Dułęba himself was sympathetic, the Finance Ministry responded blandly, "The Interministerial Petroleum Committee is aware of this dumping on the part of Limanowa ... and has discussed it. No special measures were taken." 101 And so ended, rather ignominiously, the Austrian government's measures against what it referred to as "the French Company," Limanowa.

Fear that the United States would follow France's example led to heightened skepticism in the liberal Austrian press. At the same time that the French press took up Limanowa's case, the Neue Freie Presse argued in a September article titled "The Petroleum War" that "it would be unprecedented folly for two states which are in no particular opposed to each other to let diplomatic difficulties arise all on account of a few stockholders of petroleum shares." The newspaper condemned the Austrian government for "resort[ing] to unexampled action against private interests." 102 Pub-

97 Report of October 24, 1910, ÖStA, MP, 2411.

98 Note from Limanowa, November 3, 1910, appended to file "Beseitigung," ÖStA, FM, Präs. Z2111.

${ }_{99}$ Austrian refiners to FM and Handelsministerium, October 28, 1910, ÖStA, FM, Z79052. Reports from FM and Eisenbahnministerium, November 24, 1910, ibid., FM, Präs Z2217.

100 "Beilegung der Differenzen mit der Petroleum-Licht- und Kraft-Gesellschaft LIMANOVA," December 7, 1910, ÖStA, FM, Z90481. Stéphen Pichon, the foreign minister of France, asked the French ambassador in Vienna (at Aerenthal's request) to make a public statement expressing his satisfaction with the conclusion of the affair. Note Verbale no. A/124, December 7, 1910, HHStA, MdÄ, AR, F97/10, Handelsartikel-Petroleum, folder 97 Petroleum 69a.

${ }^{101}$ Dułęba to Ritt, December 10, 1910, ÖStA, MföA, F828, Z2488-XVII, ex. 1910; Dułęba to Biliński, December 10, 1910, ÖStA, FM, Z90639.

102 "Der Petroleumkrieg," Neue Freie Presse (Vienna), September 24, 1910. Translation by U.S. State Department in NARA, RG 59, Box 4462, 363.115 V 13/33. 
lic pressure to negotiate was high in Austria-not so much out of a sense of affinity with the United States, but because consumers' interests did not appear to be served by the precedent of government discrimination against individual businesses, in particular when that discrimination was expected, short-term, to result in higher petroleum prices.

Despite the misgivings of the Neue Freie Presse, however, the danger of U.S. retaliation was never very grave. After "careful reexamination," and having witnessed the alacrity with which France had defended Limanowa, Assistant Secretary of State Wilson instructed Kerens in September to threaten "appropriate retaliatory measures" if the persecution of Vacuum was not suspended, and suggested that he "confer with [the] French Ambassador." 103 This more aggressive course of action was approved by State Department counselor Henry Hoyt, who, while admitting that "we would, of course, hold Austrians here under an American corporation to that rule," nevertheless believed that "in all such matters the Austrian government seems to be invariably unfriendly as well as tyrannical and unprincipled." 104 The problem with the State Department's new forceful tone, however, was that there was little behind it. In late October, the head of the Division for Near Eastern Affairs, Evan E. Young, confessed to Hoyt, "we have gone about as far as we safely can in intimating that we may be compelled to adopt retaliatory measures." 105 Even though Adee instructed Kerens to "leave with the Austrian authorities an impression that the controversy is now reaching a critical stage," this was little more than bluster, since the State Department was not itself authorized to take action against Austria. ${ }^{106}$ France had taken advantage of its traditional status as a financial power on which AustriaHungary depended for loans. The State Department, however, could fall back only on trade agreements which it knew that Austria-Hungary had not, strictly speaking, violated.

Nevertheless, Minister of Finance Biliński oversaw negotiations with Vacuum starting in December 1910 that led Kerens to predict in early January that "all repressive measures" would be removed "within a period of eight days." 107 In a longer letter, Kerens happily reported that Vacuum's directors believed it "would be in a better position than ever before to carry on its business in Austria-Hungary" since "they had made extraordinary preparations, by the storage of large quantities of crude oil and otherwise, for the contest which then seemed inevitable in order to adjust the caotic [sic] conditions that existed in the Austrian oil industry." 108 But Kerens's proud claims that the matter was "virtually closed so far as our Government is concerned" and that "its outcome should have a beneficial influence upon other American investments and interests in Austria-Hungary" were premature. The Austrians had not given in; they had merely shifted from a tactic of confrontation to one of cunctation. From February 1911 through the fall of 1912, Libby repeatedly complained that the repressive measures the Austrians had promised to lift were still $13 / 28$.

103 Wilson to Kerens, Washington, D.C., September 16, 1910, NARA, RG 59, Box 4462, 363.115 V

104 H. M. Hoyt to Wilson, September 16, 1910, NARA, RG 59, Box 4462, 363.115 V 13/28.

105 Young to Hoyt, October 31, 1910, ibid., 363.115 V 13/37.

106 Adee to Kerens, November 1, 1910, ibid.

107 Kerens to Secretary of State, Vienna, January 5, 1911, ibid., 363.115 V 13/55.

108 Kerens to Secretary of State, Vienna, December 31, 1910, ibid., 363.115 V 13/57. 
functionally in place. He lamented, "our enemies have been very active, and we doubt if there has been since then any serious intention on the part of the Austrian Government to restore to Vacuum the rights of which it has been so long and so unjustly deprived." He estimated that Vacuum had lost well over $\$ 1,000,000$ to date, based on a revised estimated daily loss of $\$ 2,000 .{ }^{109}$

Upon Libby's request, the State Department instructed Kerens to "declare that [the U.S.] must reserve to itself the full liberty, and without notice, hereafter to inaugurate such measures of industrial retaliation as may be found expedient from time to time to meet the exigencies of the situation."110 At the same time, State Department solicitor Joshua Reuben Clark reminded Libby that "the statement as to retaliation was a threat and that in all human probability the Austrian Government was perfectly aware that it was at the present time but an empty threat, and that they would conduct themselves accordingly." 111 Kerens soon came to agree that a "more determined attitude would have to be assumed by the United States in order to bring about a satisfactory settlement of the cases."112 Consequently, in January 1912again at Libby's suggestion-Acting Secretary of State Huntington Wilson appealed to the secretary of the treasury to consider reprisals against the Austrian government. ${ }^{113}$ He hoped to convince "the Treasury Department, through the Collector of Customs at New York, [to] retaliate against the commercial, and perhaps navigation, interests of Austria by rigidly enforcing laws which it is alleged are now rather liberally construed." 114 Both Libby and the Bureau of Trade Relations continued to pester the Treasury Department throughout the spring of 1912, but in July had still not received the "clean-cut, unequivocal, detailed statement of just what it is in a position to do." 115

By the late fall of 1912, Austria-Hungary's delaying tactics had paid off: Vacuum was ready to give up. ${ }^{116}$ On November 27, 1912, with Treasury Department and congressional action still pending, Vacuum's president in Rochester, Charles Everest, and representatives of the Austrian government signed a contract "disposing of all the controverted points between the parties" and limiting Vacuum's Austrian sales to 1,500 wagons of kerosene and 100 wagons of gasoline a year. ${ }^{117}$ The claim that "this protracted, irritating and very expensive controversy" was settled was con-

109 Kerens to Secretary of State, Vienna, January 6, 1911, ibid., 363.115 V 13/58; Libby to Secretary of State, New York, April 16, 1912, ibid., 363.115 V 13/88. Libby also noted that the actual losses of Vacuum for 1911 alone were $\$ 465,000$, not including the "loss of interest on the large capital invested and of normal commercial profits." On January 9, 1911, before a recently concluded agreement received "final and official sanction," the Austrian government fell-Ritt, Wrba, Dułęba, and the sympathetic Biliński were all replaced. The transition affected neither Austria-Hungary's relations with the United States nor government policy regarding this dispute, but it provided an excuse for further delays.

110 Knox to Kerens, Washington, D.C., March 28, 1911, NARA, RG 59, Box 4462, 363.115 V 13/72.

111 Clark summarizing interview with Mr. Libby, March 24, 1911, ibid.

112 Kerens to Knox, Vienna, March 30, 1911, ibid., 363.115 V 13/77.

113 Wilson to Franklin MacVeagh, January 19, 1912, ibid., 363.115 V 13/84.

114 John Ball Osborne (Chief, Bureau of Trade Relations) to Chandler P. Anderson (Counselor, Department of State), January 12, 1912, ibid., 363.115 V 13/85.

115 Osborne to Lester H. Woolsey (Assistant Solicitor), July 22, 1912, ibid., 363.115 V 13/93.

116 HM to MdÄ, November 29, 1912, HHStA, MdÄ, AR, F 97/10, Handelsartikel-Petroleum, folder 97 Petroleum 69c.

117 Denby to Aerenthal, Vienna, November 27, 1912, NARA, RG 59, Box 4462, 363.115 V 13/94. Austria agreed to remove all restrictions imposed on Vacuum; Vacuum agreed to withdraw its lawsuits against Austria. HM to MdÄ, November 29, 1912, HHStA, MdÄ, Administrative Registratur, F97/10, Handelsartikel-Petroleum, folder 97 Petroleum 69c. 
firmed by William Herbert Libby, the final arbiter in both his own and the State Department's opinion, on December 20, 1912.118

THE INTERACTION BETWEEN MORE THAN A DOZEN different agents of policy and practice involved in the Petroleum War sheds light on the entangled history of national governments and multinational corporations struggling to preserve their own autonomy in the caudal years of a "globalized" age. It exposes some of the key strengths and weaknesses of the two protagonists: the Austrian government and the Standard Oil Trust. If the former excelled at diplomacy, it was unable to coordinate the large and vital industry it so boldly defended against external enemies, leaving it prey to internal disruptions, disorganization, and inefficiency. If the latter had mastered the "intensified trade tactics" it had fruitfully used to gain dominance at home and abroad, it had not learned to rein in the excessive competitive zeal that kept it engaged in a dispute with what would ultimately prove to be a minor player in the global oil industry. ${ }^{119}$ But the Petroleum War also offers broader lessons that challenge binary juxtapositions of states and markets. First, it illuminates the intimate connection between diplomacy and economic activity in the context of waning European political authority (at least in the case of Austria-Hungary) and waxing American commercial might. Second, it explores the differences between government support for the activities of multinational corporations (and in particular oil companies) at home and abroad. Although corporations played a large part in extending the economic influence of the United States in this period, they did not do so without government support.

The notion of a free market is not one that operated powerfully on either side of the 1910 Petroleum War. Despite free market rhetoric, businesses-even businesses as powerful as Standard Oil-relied on diplomatic and regulatory support from their governments. According to historian Paul Sabin, "A free market has never existed in the United States, and it never will. In fact, government action is indispensable to the very functioning of capitalism. Even when the direct regulatory role diminishes, government action shapes economic outcomes through tax policy, property rights, and labor law." 120 In 1910, the U.S. and Austrian governments shared the view that it was their responsibility to defend their respective nations' position in international oil markets. The Petroleum War thus suggests parallels in the relationship between business and government in two states whose assessments of the relative value of a "free market" are generally portrayed as inconsistent. Both sides viewed their interventions not as attacks on a truly "free" market, but rather as defensive measures against an opponent who was, in essence, cheating. From the

${ }_{118}$ Libby to Secretary of State, New York, December 20, 1912, NARA, RG 59, Box 4462, 363.115 V 13/95.

119 Of course, in 1910, neither Standard nor Galician producers knew that the Galician oilfields had begun an inexorable decline. Nevertheless, the recent discoveries of major new oilfields in the Middle East, the Far East, and the New World confirmed that the future of oil exploration would not be in continental Europe. In 1910, Europe produced 28.8 percent of the world's petroleum; ten years later (1920), only 5.6 percent. "Erdölförderung der Weltteile und einzelnen Länder von 1910-1925 in 1000 Tonnen," in Schwarz, Petroleum-Vademecum, 16-17.

${ }^{120}$ Paul Sabin, Crude Politics: The California Oil Market, 1900-1940 (Berkeley, Calif., 2005), xv. 
Austrian government's perspective, defending Austrian business interests against the unfair, dishonorable, and "tyrannical" practices developed by the "Americans" (that is, Standard and Vacuum) was by no means a violation of "business ethics" (Geschäftsmoral). ${ }^{121}$

For the Americans, on the other hand, Austria was itself "tyrannical" and unreliable, and blatantly disregarded basic principles of fairness in business. Standard argued, and the State Department came to believe, that this dispute had negative implications for U.S. investments abroad. Huntington Wilson noted that the government's relation to foreign investment was defined simultaneously by its "general obligation to protect the citizens' rights, and authority to control the citizens' course by giving great or little protection, or none at all." Without government guarantees, American investors would have little security when investing abroad, and the absence of such guarantees would effectively prohibit "foreign investment in all countries except those of the highest credit and stability." 122 If Austria-Hungary qualified as such a country at the beginning of this dispute, it hardly did so by the end. As unfair as its actions were-and even the Imperial Royal Supreme Court in Vienna agreed that they were illegal-they proved effective in buying time. ${ }^{123}$ Libby thought the lesson of the entire affair was one that revealed more American weakness than Austrian. ${ }^{124}$ What the United States needed was the will to take the same kind of rapid administrative measures that Austria had taken.

Victoria de Grazia has argued in Irresistible Empire that "America's hegemony was built on European territory" when it displaced Europe's authority as the "center of vast imperial wealth" and "astute commercial know-how." ${ }^{25}$ But the Petroleum War reminds us that the trajectory so skillfully traced by de Grazia was invisible to Austria-Hungary in 1910. Insecurity about the economic might of the United States notwithstanding, Austro-Hungarian diplomacy in this dispute suggests a sense of operating from a position of strength, not weakness. In 1909, Galician production had reached its all-time peak. That its decline would be rapid and steady was unsuspected when the Petroleum War began, and unproven even when it ended. The region had experienced temporary declines in the past, and more optimistic observ-

121 "Maßnahmen zur Unterstützung der heimischen Petroleumindustrie," Vienna, June 16, 1910, ÖStA, MföA, F664, Z634.

122 Wilson, "The Relation of Government to Foreign Investment," 298.

123 The Imperial Royal Supreme Court decision is available in translation in NARA, RG 59, Box 4462, 363.115 V 13/87. The legal case was based on the details of Austrian contract law and the question of whether the Railway Ministry was legally entitled to cancel contracts before they were due to expire. The Supreme Court's ultimate decision in favor of Vacuum was an embarrassment to the Austrian government; Vacuum's agreement to withdraw its legal right to recrimination was a key component of the final settlement.

${ }_{124}$ Libby to Secretary of State, New York, December 20, 1912, NARA, RG 59, Box 4462, 363.114 V $13 / 95$.

125 Victoria de Grazia, Irresistible Empire: America's Advance through 20th-Century Europe (Cambridge, Mass., 2005), 3-5. According to Richard Leopold, reference to the United States as a world power began with John Bassett Moore's 1903 contribution of "The United States as a World-Power (1885-1902)" to the Cambridge Modern History's seventh volume, and became further popularized by Archibald Cary Coolidge and John Latané in 1906-1907. Leopold, "The Emergence of America as a World Power: Some Second Thoughts," in Braeman, Bremner, and Walters, Change and Continuity in Twentieth-Century America, 4. 
ers were confident that new fields would be found in neighboring areas to replace those that became exhausted. ${ }^{126}$

Austria's willingness to endure years of diplomatic strain in order to maintain punitive measures taken without legislative backing showed its commitment to propping up its own domestic industry-and its general lack of fear of the political and even financial power of the United States. That lack of fear, however, did not mean a complete lack of respect. According to Ernest May, "among powerful groups in all continental lands, there was ... irritation over American economic competition, animosity toward American ideas, and some alarm at a prospective American menace." 127 Austria-Hungary was not willing to challenge the State Department openly, or to proclaim boldly its indifference to retaliatory action. Rather, it dangled the possibility of an agreement before Vacuum's nose for two long years, always promising that a cancellation of the discriminatory measures was at hand. Austria's diplomatic savvy and administrative creativity enabled it to fend off the State Department successfully. This sort of passive resistance was another weapon in the arsenal of Europeans who resented the growing power of the American economy.

Austria-Hungary's "tight-rope dance" was required not only out of respect for foreign relations with the United States, however, but also because the question of how to defend the petroleum-related interests of the monarchy's own subjects was a very delicate one. Refiners included some of the more powerful financial interests in Vienna and Budapest; according to a Ministry of Trade estimate, the refining industry represented 250 million crowns of invested domestic capital, and employed $18,000-20,000$ workers. ${ }^{128}$ Measures taken in refineries' interests would not necessarily benefit either their suppliers or their customers. Austrian refiners' ability to compete with Standard was hampered not only by Standard's deep pockets and aggressive tactics, but also by artificially high crude oil prices manufactured by the government to support the Galician oil-production industry. Despite the traditional view that the Habsburg economy was rent asunder by "ideological and nationalistic motives," the story of the Petroleum War of 1910 reveals no sign of nationally or even provincially based interest groups within the monarchy itself. ${ }^{129}$ There were conflicts of interest, but they were between those who profited from high crude oil prices (producers) and low crude oil prices (refiners) or those who profited from high prices for refined products (refiners) and low prices for refined products (distributors, consumers). Only on the international stage were these deep divisions hidden behind

\footnotetext{
126 Engineer Stefan Bartoszewicz held out hope for the industry's recovery well into the 1920s. Bartoszewicz, "Rozwój przemysłu naftowego w Polsce i jego przyszłość," Przemyst Naftowy 3, no. 19 (October 10, 1928): 533. By 1912, however, signs of exhaustion were present for those willing to see them: oil production had fallen by more than 40 percent from its 1909 peak. Robert Schwarz, ed., PetroleumVademecum: International Petroleum Tables, 6th ed. (Berlin, 1929), 178. The Times noted presciently, "The Galician field is passing through a crisis which in the opinion of eminent authorities foreshadows the final wane of the field as an important producer." "Petroleum Industry: World-Wide Exploratory Work," Times (London), January 22, 1912, 22.

127 Ernest R. May, Imperial Democracy: The Emergence of America as a Great Power, 2nd ed. (Chicago, 1991), 189.

128 "Enquete über die Krise in der Mineralölindustrie," 6.

${ }^{129}$ Herbert Matis, "National Identity and Economic Conditions in Twentieth-Century Austria," in Alice Teichova, Herbert Matis, and Jaroslav Pátek, eds., Economic Change and the National Question in Twentieth-Century Europe (New York, 2000), 230.
} 
a united Austrian front representing the combined energies of the Viennese government and the oil industry it defended against the "Americans" and Standard.

In general, scholars have agreed that "the presence of multinational corporations contributed to a smooth functioning of the international economic system" in the last years before the First World War. As Akira Iriye has explained, "the growth of multinational enterprises ... served to develop transnational interests and solidarities conducive to international order." 130 This Petroleum War suggests that a multinational company's own transnational interests did not necessarily prevent it from generating nationalistic animosities in the various countries in which it operated. It shows both the connections between American and European markets and the limits of shared interests and perspectives. The Petroleum War of 1910 is therefore an example of both international ("between nations") and transnational ("across national boundaries") history. ${ }^{131}$ Although the Austrian Foreign Ministry and the U.S. State Department did not describe their dispute using this vocabulary, the question of whether the Petroleum War was international or transnational was itself a bone of contention between them. To what extent was the United States entitled to intervene in or even comment on a dispute between the Austrian government and a company incorporated within Austria, given that its shareholders were American citizens? Although Aerenthal insisted on Vacuum's "Austrian" status for legal reasons, there was never any doubt on either side of this debate that Vacuum was in some meaningful sense an American company. Even when proprietors of stock moved from state to state, they took their nationality with them.

Both Austria and the United States understood the limits of the "multinationalism" of enterprise - that, in the words of Charles Maier, "although firms plant branches abroad and aspire to international activity, they are clearly rooted in a home country." 132 Austria's expectation that it could challenge Standard with impunity was based on its mistaken assumption that the State Department would tolerate-or even appreciate-foreign attacks on a company targeted for prosecution at home. The State Department could not allow such presumption to stand. By the end of this dispute, it was clear to everyone involved that mobility of capital did not always mean that corporations were more powerful than states. Sometimes it meant that they needed states' help more than ever before.

\footnotetext{
130 Akira Iriye, Global Community: The Role of International Organizations in the Making of the Contemporary World (Berkeley, Calif., 2002), 130.

131 Akira Iriye, "Internationalizing International History," in Bender, Rethinking American History in a Global Age, 51.

132 Maier, "Consigning the Twentieth Century to History," 822.
}

\begin{abstract}
Alison Frank is John L. Loeb Associate Professor of the Social Sciences at Harvard University, where she has taught in the History Department since 2005. She is the author of Oil Empire: Visions of Prosperity in Austrian Galicia (Harvard University Press, 2005). She is currently writing a book on the Adriatic port city of Trieste from 1719 until 1919, in which she investigates Austria-Hungary's pretensions to becoming a global commercial maritime power.
\end{abstract}

